\title{
Д.Е. Селиванов
}

\section{ПРОБЛЕМА ПРОИСХОЖДЕНИЯ И СОДЕРЖАНИЯ ЭТНОНИМА ТЕЛЕ В СОВРЕМЕННОЙ ЭТНОЛОГИЧЕСКОЙ НАУКЕ}

\begin{abstract}
Данная статья направлена на выявление и рассмотрение основных факторов социально-политического развития тюркских племен теле с периода возникновения данного этнонима вплоть до падения первого Тюркского каганата (Вечного Тюркского Эля). Целью данной статьи является не только реконструкция истории возникновения и межгосударственного взаимодействия ранних представителей племен теле, но и выявление основных современных этнологических проблем, связанных с изучением этнонима. Также определяются основные пути решения данной проблемы в современной этнологической науке.

Ключевые слова: теле; Первый Тюркский Каганат; гунны; теленгиты; динлины.
\end{abstract}

Прежде чем разбирать проблему социальнополитического развития тюркских племен теле, необходимо остановиться на понимании этого этнонима. Стоит помнить, что теле, по сути своей, не является единым, отдельным этносом и представляет собой скорее конфедерацию таких племен, как, в первую очередь, вэйхо (уйгур) сеяньто и тубо [1. С. 233]. Упоминания о племенах теле встречаются в трех основных исторических источниках. Самыми ранними являются летописи китайских династий Суй и Тан. Это такие документы, как Вэй Шу (китайское название, История династии Вэй) и Лю Сюй (китайское название Старая история династии Тан). В последнем случае рассматривается история, по сути, предшествовавшая династии Тан, т.е. период Первого Тюркского Каганата и последующего за ним разделения государства на Восточный и Западный Каганаты. Проблема китайских источников заключается в крайней их труднодоступности для российских исследователей, так как перевод этих двух документов на данный момент носит частичный характер и практически не затрагивает интересующую нас информацию.

Следующим и более доступным источником является труд исламского исследователя Рашид ад Дина «Джами ат таварих», или «Сборник летописей» [2]. Данный сборник является первой попыткой систематизации имеющейся информации касательно тюркских племен в составе монгольской империи. Положительными качествами источника является широкий спектр затронутых в исследовании этносов. Однако, несмотря на общую, специфичную для ранних исламских исследователей, стилистику повествования (уделяющую огромное внимание хронологии происхождения отдельных исторических личностей и их родов), в данном источнике очень скупо представлена информация о происхождении племен теле, в частности теленгутов.

К наиболее проработанным на сегодняшний день в российской этнологической науке относятся сибирские летописи и документы XVII в., в частности «переписные листы» того времени. Более того, особое место в российской этнографии занимают более поздние пере- воды китайских источников Н.Я. Бичурина [3] и как дополнение к ним - работа Н.В. Кюнера «Китайские известия о народах Южной Сибири» [4]. Минусом данных источников является их хронологическая соотнесенность с более поздним периодом. Кроме того, проработанность этих источников свидетельствует об исчерпывающем характере имеющейся информации на базе данных трудов.

Следует отметить, что проблема возникновения этнонима теле до сих пор является дискуссионной в современной этнологической науке. Существует несколько точек зрения касательно возникновения этнонима теле, все они связаны с определенной источниковой базой, на которую опирался автор теории. Выделяются три основных подхода в изучении этнонима теле.

Сторонником и основным приверженцем первой теории можно назвать Леонида Павловича Потапова, отечественного этнографа, посвятившего жизнь изучению народов Южной Сибири и Тувы. По мнению Потапова, теле является самоназванием группы тюркских племен (перечисленных выше). Кроме того, исследователь считал: «Невозможно представить, чтобы многочисленные носители этнонима теле заимствовали его [этноним] из китайских анналов, где он фигурирует главным образом в связи с изложением истории Тюркского каганата» [1. С. 234].

Более интересной, с точки зрения вопросов центрально-азиатской этнографии, версии придерживается Л.Н. Гумилев, считая племена теле потомками хунну [5. С. 65]. Свои выводы Гумилев делал, основываясь на сходствах в языковой структуре уйгуров, которые входили в племена теле и хунну. Данная версия является дискуссионной и не раз ставилась под сомнение, в том числе такими специалистами, как П.Б. Коновалов [Там же. С. 66].

Наконец, третьей дискуссионной версией происхождения этнонима теле, перекликающейся с гипотезой Л.Н. Гумилева, является проблема этноса динлинов. Как известно, в целях получения новых рудоносных территорий хунну захватывали северные территории, в том числе Южную Сибирь, места проживания древнего племени динлинов. Таким образом, суще- 
ствует точка зрения, что племена теле, так или иначе, являются потомками одного из древнейших племен, населявшего территорию современной Южной Сибири, Минусинской котловины и Алтая [6. С. 16].

Проблема происхождения этнонима динлин и связи его с этнонимом теле является одной из значимых в тюркологии, так как первый, несомненно, имеет китайское происхождение [7. С. 235]. Кроме того, сам устоявшийся этноним теле может носить китайское происхождение, так как он использовался, в том числе, для определения всех известных тюркских племен (Большой китайско-русский словарь 铁勒 - tie(3)le(4) - уст. тюрки). Эволюция терминов Dingling-Tiele в китайском языке представляется возможной. Таким образом, несмотря на логичность точки зрения Л.П. Потапова, теорию китайского происхождения этнонима теле не стоит окончательно убирать с дискуссионной позиции.

На все вышеперечисленные вопросы: являются ли динлины предками теле, являются ли теле потомками хунну и где искать следы хунну в современной науке, окончательного ответа нет по одной причине - отсутствие источников, не позволяющее заполнить временные промежутки трансформаций этнических общностей с соответствующими этнонимами.

В силу использующихся на сегодняшний день источников существуют два основных временных пробела, касающихся племен теле, которые представляют собой наибольший интерес для исследователей. Первый пробел - это период между упадком хунну и первым появлением племен теле в китайских летописях. Падение хунну произошло во II в. н.э., в то время как первое упоминание племен теле датируется концом IV в. Таким образом, появляется существующая на сегодняшний день проблема возможности преемственности между племенами теле и хунну. Причины отсутствия источников относительно данного временного промежутка просты - основная информация по племенам того времени записывалась китайскими летописцами. А как можно понять из даты II-IV вв. н.э. - данный период как раз падает на смутное время - Троецарствия в Китае, что отрицательно сказалось на полноте источниковой базы.

Вторым проблемным периодом для изучения истории племен теле является период XIII-XVII вв. Именно в XIII в. происходит основание монгольской династии Юань, а также процессы подчинения тюркских племен на западе Китая. Интересы монголов сосредотачиваются на процессах в Китае и Средней Азии, истории Южной Сибири уделяется минимальное внимание. После чего значительное количество информации появляется только в связи с колонизацией русскими Сибири и изучением непосредственных потомков племен теле - теленгитами, телеутами, телесами. Промежуток между этими двумя этапами освящен в историографии слабо.

Причина слабого освящения кочевых племен в данном случае может крыться и в особенностях политического устройства их сообществ. Иными словами, гово- ря о племенах теле, или даже о динлинах, мы не можем проводить параллели с типичным представлением о государстве. Безусловно, государственные образования на базе племен теле существовали, например Уйгурский Каганат или сообщество племен токуз-огуз. Однако в данном случае появляются две основные проблемы изучения этих самых государственных образований - отсутствие фиксированной территории и патрилинейная система родства.

Говоря о любом государстве, первое, что приходит на ум, - территория, обладающая установленной границей. И именно это заблуждение чаще всего приводило к путанице, появляющейся в источниках относительно племен теле. Трудность заключалась в точном определении, где заканчивалась территория теле и начиналось другое государство, по тому принципу, что кочевые родоплеменные общины того времени не имели фиксированных территорий. Территория племен теле варьировалась от сезона и зависела от состояния пастбищ и военных набегов других племен, что, безусловно, затрудняет археологические реконструкции.

Более того, патрилинейная система родства привела к существованию огромного количества сеоков (родов), что также приводит к затруднению в определении принадлежности определенного сеока к определенной группе племен.

Соответственно, на сегодняшний день, чтобы решить проблемы преемственности хунну и последующих народов, стоит решить проблемы временных разрывов между хунну и теле, а также наполнить фактологией промежуток между XIII и XVI веками н.э., что важно, в первую очередь, для выяснения истории современных потомков теле. Кроме того, при решении данной проблемы отдельное внимание следует уделить отсутствию фиксированных границ у племен теле а также проблеме обилия сеоков как следствие существовавшей патрилинейной системы.

Сегодня существуют два основных пути решения данных проблем. В первую очередь, максимальные усилия стоит сфокусировать на дальнейшей переводческой деятельности китайских архивов. По сути, основная загадка динлинов, хунну, теле кроется именно в китайских летописях периода Троецарствия. Вторым путем решения данных проблем является систематизация имеющейся информации о современных известных потомках племен теле, таких как теленгиты, телеуты, телесы. В частности, изучение процессов миграции, рассмотрение отдельных очагов расселения потомков теле (Южный Алтай, Кузбасс, Синьцзян-Уйгурский Автономный Район, Восточный Казахстан, Томская область) могут положительно сказаться на решении проблемы «наполнения» второго временного промежутка XIII-XVII вв. н.э.

Дальнейшая деятельность в этом направлении, возможно, поможет решить один из важнейших вопросов этнологической науки - судьбу этноса хунну, а именно доказать, являются ли племена теле потомками хунну или 
нет. Кроме того, исследования в данном направлении могут открыть свет на проблему древнейшего этноса Юж- ной Сибири - динлинов, а также проблему культурных параллелей между древними тюрками и Китаем.

\section{ЛИТЕРАТУРА}

1. Потапов Л.П. Этноним Теле и Алтайцы // Тюркологический сборник к 60-летию А.Н. Коновалова. М. : Наука, 1966. С. $233-240$.

2. Рашид ад Дин. Джами ат Таварих (Том III), Сборник Летописей. М. : Изд-во Академии наук СССР, 1952.

3. Бичурин Н.Я. Собрание сведений о народах, обитавших в Средней Азии в древние времена // III приложения. М. : Изд. Академии наук СССР, 1953. $325 \mathrm{c}$.

4. Кюнер Н.В. Китайские известия о народах Южной Сибири, Центральной Азии и Дальнего Востока. М. : Изд-во Вост. лит-ры, 1961.350 с.

5. Гомбожапов А.Д. Кочевые цивилизации Центральной Азии в трудах Л.Н. Гумилева. Улан-Удэ : Изд-во Бурят. науч. центра СО РАН, 2010. $148 \mathrm{c}$.

6. Кызласов Л.Р. История Южной Сибири в Средние века. М. : Высшая Школа, 1984. 167 с.

7. Юань Кэ. Мифы Древнего Китая. М. : Наука, 1965. 496 с.

\section{Selivanov Dmitriy E. Tomsk State University (Tomsk Russia). E-mail: sde29study@yandex.ru}

\section{THE ORIGIN AND THE MAINTENANCE PROBLEMS OF “TELE” ETHNONYM IN THE MODERN ETHNOLOGY}

Keywords: Tele, First Turkic Khaganate, hunnu, telengit, dinling.

This article is directed to identification and consideration of major social political development factors of Turkic "tele" tribes since the period of this ethnonym emergence up to falling of the first Turkic Khaganate (Eternal Turkic Ale). The purpose of this article is not only reconstruction of the history of emergence and interstate interaction of early representatives of "tele" tribes, but also the main modern ethnological problems identification which one are connected with studying of an ethnonym. In the article the main solutions of this problem in modern ethnology are also defined. Author's efforts dedicate to renew and rebuilding the systems of ancestors between three ethnonyms: dingling - tele - telengit. As author says now there is an opinion that dingling ethnonym is a strict ancestor of tele, and tele ethnonym is an ancestor of telengit. Moreover, there is a point of view that hunnu ethnonym somehow related to this system and could be anscestor of tele or telengit. According to author all these opinions today haven't got any strict proves and more hypotheses than direct facts. Efforts of author refer to find decisions for this problems and opportunity to prove or dispose those hypotheses. There are three parts of the article. In the beginning author summarizes today`s sources for "tele" ethnonym problem. The second part contents analysis of sources in the prism of opportunity to use it for further research. According to the author most of sources are overused right now, so there are a lack of interest to them for researches. The problem of sources leads to the problem of "time gaps". In the author's opinion as far as nowadays only few sources tells us about tele ethnonym, there are a lack of information about periods which one is not refer to this sources. According to author there are three main gaps which one cannot allow us right now prove or dispose hypotheses about tele ethnonym and it's ancestors. The third part of article is directed to find a way for overcoming time gap problem. Author defines three common ways for that. The author concludes first of all that there is situation of lack of data and proves about tele ethnonym problem. Moreover, in case of proving of system dingling-tele-telengit, the telengit ethnonym can be more ancient than we supposed before. In this case efforts can be useful for tourist situation for regions of telengit living (mostly Altai, South of Kemerovo region, Tomsk Region). In case of dispose all these hypotheses telengit people get no harm, because situation stays the same.

\section{REFERENCESE}

1. Potapov, L.P. (1966) Etnonim Tele i Altaytsy [Ethnonym Tele and Altaians]. In: Klyashtorniy, S.G. (ed.) Tyurkologicheskiy sbornik k 60-letiyu A.N. Konovalova [Turcologica. To the 60th anniversary of A.N. Kononov]. Moscow: Nauka. pp. 233-240.

2. Rashid ad Din. (1952) Dzhami at Tavarikh [The Jāmi' al-tawārīkh]. Vol. 3. Moscow: USSR AS.

3. Bichurin, N.Ya. (1953) Sobranie svedeniy o narodakh obitavshikh v Sredney Azii v drevnie vremena [Data about the peoples inhabiting Central Asia in ancient times]. Moscow: USSR AS.

4. Kyuner, N.V. (1961) Kitayskie izvestiya o narodakh Yuzhnoy Sibiri, Tsentral'noy Azii i Dal'nego vostoka [Chinese news about the peoples of South Siberia, Central Asia and the Far East]. Moscow: Vostochnaya literatura.

5. Gombozhapov, A.D. (2010) Kochevye tsivilizatsii Tsentral'noy Azii v trudakh L. N. Gumileva [Nomadic civilisations of Central Asia in the works of L.N. Gumilev]. Ulan-Ude: SB RAS.

6. Kyzlasov, L.R. (1984) Istoriya Yuzhnoy Sibiri v srednie veka [History of Southern Siberia in the Middle Ages]. Moscow: Vysshaya shkola.

7. Yuan Ke. (1965) Mify Drevnego Kitaya [Myths of Ancient China]. Translated from Chinese by E.I. Lubo-Lesnichenko, E.V. Puzitsky, V.F. Sorokin. Moscow: Nauka. 